\title{
A CASE STUDY OF INTERCULTURAL COMMUNICATION: SMALL TALK AT DIFFERENT STAGES OF RELATIONSHIP BETWEEN A VIETNAMESE AND AN AMERICAN
}

\author{
Hoang Thi Thu Hoai ${ }^{1}$, Nguyen Thuy Linh ${ }^{2}$, Nguyen Thi Hong Ha ${ }^{2 *}$ \\ ${ }^{\prime}$ Thai Nguyen Medical College \\ ${ }^{2} \mathrm{TNU}$ - School of Foreign Languages
}

\section{ABSTRACT}

In the trend of integration today, Vietnamese people have more opportunities to contact, mingle and work with English speakers. This leads to the fact that equipping university students with sufficient language knowledge and skills is crucial. In Vietnam nowadays, there have been a lot of studies on enhancing teaching methodology to help language students meet the standard required by MOET; however, social and cultural aspects have not been paid enough attention. This study aims at investigating three main features: degree of directness, formality and politeness, of an intercultural communication study "Small talk between an American and a Vietnamese". It is designed as a case study to examine communication between individuals of different cultures: how communication evolves and its relationship with personal and cultural factors. The results of the study have consolidated the theories existing so far: when people of different cultures reach different stages of personal relationships, their language changes.

Keywords: Linguistics; intercultural communication; small talk; culture; relationship.

Received: 02/7/2019; Revised: 27/8/2019; Published: 28/8/2019

\section{NGHIÊN CÚU GIAO TIẾP LIÊN VĂN HÓA: ĐặC ĐIỂM HộI THOẠI NGẮN THEO TƯNG GIAI ĐOẠN PHÁT TRIỂN MỐI QUAN HỆ GIŨ் MỘT NGƯờI VIẸT NAM VÀ MỘT NGƯờI MỸ}

\author{
Hoàng Thị Thu Hoài ${ }^{1}$, Nguyễn Thùy Linh ${ }^{2}$, Nguyễn Thị Hồng Hà ${ }^{*}$ \\ ${ }^{I}$ Truòng Cao Đẳng Y tế Thái Nguyên \\ ${ }^{2}$ Khoa Ngoại ngũ - ĐH Thái Nguyên
}

\section{TÓM TẮT}

Trong xu hướng hội nhập hiện nay, công dân Việt Nam có cơ hội tiếp xúc, giao thiệp xã hội và làm việc với những người nói tiếng Anh. Điều này dẫn tới việc trang bị cho sinh viên đại học ở Việt Nam các kiến thức và kỹ năng ngôn ngữ cần thiết là cực kì quan trọng. Ở Việt Nam hiện nay có khá nhiều các nghiên cứu về phương pháp giảng dạy ngoại ngữ nhằm giúp người học đạt được chuẩn đầu ra về ngôn ngữ đặt ra bởi bộ Giáo dục và Đào tạo; tuy nhiên, các khía cạnh văn hóa xã hội của ngôn ngữ chưa được quan tâm nhiều. Nghiên cứu này là một nghiên cứu trường hợp trong lĩnh vực giao tiếp liên văn hóa tiến hành nhằm tìm hiểu ba đặc điểm: Mức độ riêng tư, mức độ trang trọng và mức độ trực tiếp trong giao tiếp xã hội của một cá nhân người Mỹ và người Việt Nam. Nghiên cứu này tìm hiểu giao thiệp giữa các cá nhân thuộc các nền văn hóa khác nhau: Sự phát triển của giao tiếp và mối quan hệ của nó với các yếu tố cá nhân và văn hóa. Kết quả nghiên cứu đã khẳng định lại các lý thuyết về giao tiếp liên văn hóa: Khi mối quan hệ giữa các cá nhân thuộc các nền văn hóa khác nhau phát triển đến từng giai đoạn nhất định thì ngôn ngữ của họ cũng thay đổi theo.

Từ khóa: Ngôn ngũ học; giao tiếp liên văn hóa; chuyện trò; văn hóa; mối quan hệ.

Ngày nhận bài: 02/7/2019; Ngày hoàn thiện: 27/8/2019; Ngày đăng: 28/8/2019

* Corresponding author. Email: hongha.sfl@tnu.edu.vn

DOI: https://doi.org/10.34238/tnu-jst.2020.03.1782 


\section{Introduction}

It is generally accepted that language essentially originated from the reality of culture: language can not be explained without looking at its cultural context. As a result, to learn a language means to learn its culture as well.

In most English speaking countries, it is normal and necessary to make small talk in certain situations. Small talk is a casual form of conversation on everyday matters, especially on social occasions. Small talk can be a big challenge for those from different cultures because of cultural gaps. It is not only the language but, more importantly, the cultural differences that cause difficulties in communication and human relationships. In academic environment students are primarily taught the language with little concentration on cultural aspects, so their cultural knowledge is, to a certain extent, limited. Lacking small talk skills makes it difficult for people in general and for language students in particular, to build social relationship and communication skills although they may be proficient at language skills.

The above reasons inspire me to carry out the case study to investigate the language changes along the relationship development between a Vietnamese and an American.

\section{Literature review}

The following part represents theories in intercultural communication. According to the penetration theory [1, pp. 160], the personality nature of the person is like a multilayered onion. If you peel the outer skin from onion, you will find another beneath it. And if you remove that layer, you will expose to the third, and so on. Like a person, beneath the superficial areas of identification, such as preferences, there lie in the inner core the public views, values, beliefs, semiprivate attitudes, self-concept and deeply-felt emotions that can only be revealed to some people according to the levels of the relationships.
- The breath dimension (peripheral areas) contains biographical characteristics: personal history, hometown, college major...

- The depth dimension (more centre, personal and core areas) contains the fears selfconcept, basic values...

John W Thibault believes that social relationships and the interaction between people can be understood in terms of the exchange of rewards and costs incurred during interaction [2, pp. 998]. Rewards are outcomes that are valued by the receiver. Some common rewards are good feelings, prestige, economic gain and fulfillment of emotional needs. Costs are outcomes that the receiver does not wish to incur including time, energy and anxiety.

Finally, stages in interpersonal relationship are mentioned. There are a number of ways to divide interpersonal relationship into different stages. In a very general sense, relationships are placed on a continuum of intimacy: strangers, acquaintances, friends and lovers. Here in this article I present three most popular scientific classifications by different linguists.

Thibault speculates that participants in the conversation usually pass through the following stages:

(1) Sampling - searching out others who fit our needs and who rewards us.

(2) Bargaining - working with on other to develop a relationship that is mutually satisfying to both.

(3) Commitment - forming bounds between each other.

(4) Institutionalization - publicly affirming that the relationship has an ongoing status such as marriage, business partnership, adoption and friendship.

However, according to Knapp (1973), there are five stages in interpersonal relationship development: initiating, experimenting, intensifying, integrating and bonding. In this study, I support the view of Knapp and use this classification as a research framework. I am going to present his ideas in the next part. 
Privacy mainly concerns discussion topics that people prefer to talk about (Table 1).

Table 1. Privacy in intercultural communication

The breath dimension (peripheral areas) contains biographical

General Hometown, characteristics: study, work/ personal history, job, an English hometown, college speaking major...

country, family, The depth dimension current event, (more centre,

Medium weather... personal and core areas) contains the fears self-concept, basic values...

Private Money, sex, class status/racial issue, age, weight...

[Nguồn: 3, pp. 32]

Formality is shown in greeting rituals and address terms (Table 2).

Table 2. Formality in intercultural communication

\begin{tabular}{|c|c|c|}
\hline & Rituals & Response rituals \\
\hline Formal & $\begin{array}{l}\text { - Good morning. } \\
\text { - Nice to see you. } \\
\text { - Hello, Robert. } \\
\text { - How are you? } \\
\text { - Hi, Bob. } \\
\text { - How have you } \\
\text { been? } \\
\text { - What's happening? } \\
\text { - What's new? } \\
\text { - How are you } \\
\text { doing? } \\
\text { - How you doing? } \\
\text { - Long time, no see. }\end{array}$ & $\begin{array}{l}\text { - Good morning. } \\
\text { - Yes, it's been } \\
\text { quite a while. } \\
\text { - Hello, Kathryn. } \\
\text { - Fine, thanks. } \\
\text { And you? } \\
\text { - Hi, Kathryn. } \\
\text { - Alright. } \\
\text { - Pretty good. } \\
\text { - Not much. } \\
\text { - Nothing. } \\
\text { - OK. } \\
\text { - Not bad } \\
\text { - Yeah! }\end{array}$ \\
\hline
\end{tabular}

Indirectness is shown in how speakers achieve their purpose (Table 3 ).

Table 3. Indirectness in intercultural communication Indirect Small talk -> By the way $->$ Purpose Direct Purpose -> By the way -> Small talk

I follow Knapp' relational stages [5] outlined below:

(1) Initiating: This stage includes small talk, opening lines and initial reactions to the others. This stage is dominated by the conventions modes of address like "Hi, how are you?", "Fine, and you?"...
(2) Experimenting: At this stage people begin to try to discover the unknown and engage in a lot of small talk in order to uncover topics and areas about others that they can relate to effectively.

(3) Intensifying: During this stage, the participants find information of deeper areas of each personality. They engage in small talk with deepening relationship and self-disclosure. They begin to use informal language.

(4) Integrating: This is the stage when the pairs achieve a sense of "coupling". They speak and act as a unit, develop a shared history, and merge their social circles. Part of each person is blended into the relationship.

(5) Bonding: This final stage in relationship development occurs when the couple undergoes a public ritual and formally contracts their relationship. Marriage is the most common form of bonding, and others are intimate friendships, christenings, adoptions and business partnerships.

\section{Methodology}

The aims of this research is to investigate how small talk between a Vietnamese and an American changes along personal relationship development. Specifically, it focuses on:

(1) Investigating how degree of privacy changes through personal relationship development.

(2) Investigating how degree of formality changes through personal relationship development.

(3) Investigating how degree of directness changes through personal relationship development.

This study is designed as a case study to investigate how small talk is used at each stage of relationship development between a Vietnamese and an American.

There have been two participants in the study: the Vietnamese is Nguyen Thi Hong Hanh - a fourth-year English major in Thai Nguyen Teacher's Training College, aged 23 and the American is Michael Ramos - a volunteer teacher of English in Thai Nguyen Information Technology Faculty, aged 62.

Each small talk between them was recorded and analysed in terms of: privacy, formality and directness. 
Table 4. Topics and privacy in small talk

\begin{tabular}{|c|c|c|c|}
\hline Stages & Recording & Topic & Privacy \\
\hline \multirow{2}{*}{ Initiating } & 1 & Superficial background (study subject, time in here, teaching subject). & \multirow{2}{*}{ General } \\
\hline & 2 & Weather, the settings. & \\
\hline \multirow{3}{*}{ Experimenting } & 3 & Drinking, culture, study, job. & \multirow{3}{*}{ Medium } \\
\hline & 4 & Weather, activity, a common friend, job. & \\
\hline & 5 & Study, current events. & \\
\hline \multirow{4}{*}{ Intensifying } & 6 & Holiday, goods, hometown, travelling, job, family. & \multirow{4}{*}{ Medium } \\
\hline & 7 & Bar, activity, a friend. & \\
\hline & 8 & Activity, job, traffic, past experience. & \\
\hline & 9 & Weekend activity, drinking, job. & \\
\hline \multirow{11}{*}{ Integrating } & 10 & Love, marriage, hobbies. & \multirow{11}{*}{ Private } \\
\hline & 11 & Job, drinking. & \\
\hline & 12 & Love, activity. & \\
\hline & 13 & Goods, activity. & \\
\hline & 14 & Study, job, a friend. & \\
\hline & 15 & A friend. & \\
\hline & 16 & Health, job. & \\
\hline & 17 & Activity, drinking, a friend. & \\
\hline & 18 & Study, job, a friend, love, marriage. & \\
\hline & 19 & Culture, everyday activity, job. & \\
\hline & 20 & Language, financial problem. & \\
\hline Bonding & None & None & None \\
\hline
\end{tabular}

\section{Results and discussion}

\subsection{Privacy}

Privacy is the element that changes dramatically in the process of relationship development. It depends on the small talk topics at each stage. As a result, to investigate the degree of privacy it is necessary to examine topic used by the participants. The degree of privacy in each stage of relationship can be worked out by the highest private topics.

Table 4 shows the degree of privacy along the stages of relationship development between the two participants - a Vietnamese and an American. There was a rise in the degree of privacy along the relationship development. At the first stage, initiating, the degree of privacy was the lowest. In experimenting and intensifying stages, it rose to medium level. In the last stage, integrating, the degree of privacy reached private level. Another outstanding point here was that the initiating stage passed quickly after two first small talks, which indicates the fact that small talk is an effective tool to boost interpersonal relationship.

\subsection{Formality}

There was a gradual decrease in the degree of formality along the relationship development. When the two participants first met (or their relationship was at the initiating stage), the degree of formality was the highest. Both of them were cautious and they chose to talk formally in order not to be considered "impolite". At the second stage experimenting, the degree of formality dropped to the medium level. The greeting rituals and address terms also changed: formal phrases were used less and slightly more informal phrases were used more. Then comes the next stage - intensifying. At this stage, the participants began to use informal language. The greetings and responses were quite flexible depending on the speakers' real situations. At the last stage - integrating, the degree of formality was low, at clearly informal level. Greeting rituals seemed not to be rituals but real questions showing the speaker's concern to the hearer. 
Table 5. Greeting rituals/ responses and formality in small talk

\begin{tabular}{|c|c|c|}
\hline Stages & Greeting rituals and responses & Degree of formality \\
\hline Initiating & $\begin{array}{l}\text { - Nice to see you. } \\
\text { - I'm glad to see you. } \\
\text { - Good morning, Mr Ramos. } \\
\text { - Good morning, Hanh. }\end{array}$ & Formal \\
\hline Experimenting & $\begin{array}{l}\text { - Good afternoon. } \\
\text { - Hello, Mr Ramos. } \\
\text { - Hello, Hanh. } \\
\text { - How are you? } \\
\text { - How are you doing now? } \\
\text { - I'm fine, thank you. What about you? } \\
\text { - How have you been? } \\
\text { - I'm OK. }\end{array}$ & Medium \\
\hline Intensifying & $\begin{array}{l}\text { - Hi, Michael, how you doing? } \\
\text { - I'm OK. } \\
\text { - OK, and you? } \\
\text { - I'm alright! } \\
\text { - Pretty good! }\end{array}$ & Informal \\
\hline Integrating & $\begin{array}{l}\text { - How you doing? } \\
\text { - Pretty good! } \\
\text { - How have you been? } \\
\text { - I'm fine. } \\
\text { - Hi, Michael. Do you have anything new these days? } \\
\text { - Hey, Michael. } \\
\text { - Not very well. } \\
\text { - Not bad. } \\
\text { - Not very good. } \\
\text { - I'm very fine. } \\
\text { - Not bad, not good, so so all the time. } \\
\text { - How is your teaching practice? } \\
\text { - How is your weekend? }\end{array}$ & Informal \\
\hline Bonding & None & None \\
\hline
\end{tabular}

\subsection{Indirectness}

Table 6. Indirectness in small talk

\begin{tabular}{|c|c|c|}
\hline Stages & Topics used before the main purpose & Degree of indirectness \\
\hline Initiating & - ------------ & --------------- \\
\hline Experimenting & $\begin{array}{l}\text { Teaching practice (1) } \\
\text { Fulbright meeting (2) } \\
\text {-> borrow the TOEFL book }\end{array}$ & \\
\hline \multirow[t]{2}{*}{ Intensifying } & $\begin{array}{l}\text { Tet holiday (1) } \\
\text { A kind of goods (2) } \\
\text { A plan for Tet (3) } \\
\text {-> An invitation }\end{array}$ & Indirect \\
\hline & $\begin{array}{l}\text { Asking about how Tet is celebrated (1) } \\
\text { Reason: stomach (2) } \\
\text {-> refusing the invitation }\end{array}$ & Indirect \\
\hline \multirow{3}{*}{ Integrating } & $\begin{array}{l}\text { Asking about the schedule of the class (1) } \\
\rightarrow \text { A request to join the class }\end{array}$ & Medium \\
\hline & $\begin{array}{l}\text { Asking about boyfriend (1) } \\
->\text { joking about her relationship with a common friend. }\end{array}$ & Medium \\
\hline & $\begin{array}{l}\text { Reason for borrowing a book (1) } \\
->\text { borrowing the book }\end{array}$ & Medium \\
\hline
\end{tabular}


There was a decrease in the degree of indirectness along the relationship development. At the initiating stage, no data on indirectness were recorded. It can be assumed that trying to reach a particular goal in the first talks may create bad impressions and may lead to the assumption that the speaker is trying to take advantage of them. At the experimenting and intensifying, the degree of indirectness was high. Many things had been exchanged before the main purpose was revealed. At the integrating stage, the degree of indirectness dropped to medium level, which means that the participants now were more direct in revealing their purposes. It is interesting to note that the degree of indirectness did not reach the highest level - direct.

\subsection{Implications}

\subsubsection{Awareness of privacy}

At the early stages of relationship, the degree of privacy is quite low. Communicators should not give more information as required and the topics should be quite general such as weather, current events, and job... When people first meet, they should be more cautious and sensitive about privacy and wellaware of little responses from the others so that they do not break the small talk right at the beginning.

When the relationship progresses, the degree of privacy rises and people can more easily choose what to talk about. The range of topics can be extended to more private ones such as personal viewpoints, money, politics... You just can be totally free to choose the topics when you reached very close relationships such as close friends or intimate colleagues.

\subsubsection{Awareness of formality}

In contrast to privacy, formality decreases along the stages of relationship. Using appropriate greeting forms and address terms is of great importance in successful small talk. Communicators should be aware that depending on the stage that they are at, degree of formality must be different. Formality expresses respect to other people although it also expresses distance in relationship. In contrast, informality can cause impoliteness at the early stages but proper intimacy at the later stages.

\subsubsection{Awareness of indirectness}

At early stages of human relationship, culture shock and misunderstanding occur in small talk due to cultural assumptions of the way transferring information directly or indirectly. How to perform small talk successfully at these stages requires awareness of choosing indirect strategies to keep face for oneself and to save face for others. When people become more intimate they can talk more directly; now directness is highly appreciated and it is considered as the quality of sincerity - a necessary ingredient in true friendships and other intimate relationships.

\subsubsection{Developing empathy}

Developing empathy is an important skill to overcome problems of misunderstandings in intercultural communication. In small talk an empathetic communicator must accept that not all people have the same view of the world. If someone of different cultures he does not know well speaks in the way that is against his expectation or is not accepted in his culture, he should not judge that person immediately; otherwise, that person may feel defensive towards him. Because cultures are not the same, initial gaps must be tolerated for successful communication and a future relationship.

\section{Conclusion}

In summary, the case study has shown an investigation of small talk in intercultural communication between a Vietnamese and an 
American. It examines carefully how the small talk changed when the human relationship developed in terms of privacy, formality and directness. Then based on the findings it supplies some suggestions which may be helpful to meet the demand of successful communication. Hopefully, the results of the study can bring benefits to people in general and students who are going to step into their adult social and professional lives in particular. Ultimately, it serves the purpose of enhancing people's communicative competence.

\section{REFERENCES}

[1]. E. Griffin, A First Look At Communication Theory. McGraw-Hill College, 1991.

[2]. R. F. Verderber and K. S. Verderber, InterAct: Using Interpersonal Communication Skills (Wadsworth Series in Speech Communication) 8th Edition. Wadsworth Pub Co, 1997.

[3]. Q. Nguyen, Intercultural communication. VNU publisher, 1996.

[4]. B. Tillitt and M. N. Bruder, Speaking Naturally: Communication Skills in American English. Cambridge University Press, 1985.

[5]. M. L. Knapp, Social intercourse: From greeting to goodbye. Boston: Allyn \& Bacon, 1987.

[6]. J. Thibaut and K. Harold, Social Exchange. McGraw Hill, 1959. 